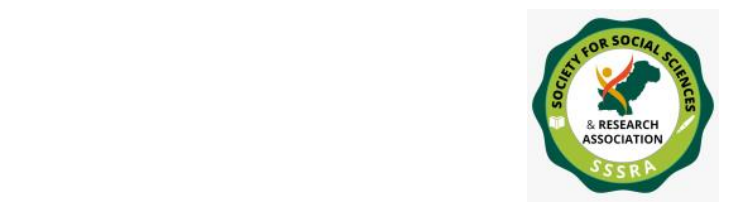

Always at War: An Analysis of

\title{
ALWAYS AT WAR: \\ AN ANALYSIS OF FEAR IN CONTEMPORARY POLITICS
}

\author{
Dr. Lubna Ahsan \\ University of California \\ United States \\ lubnaahsan12@gmail.com
}

\begin{abstract}
A culture always at war, America's political discourse has become saturated with hatred and fear. The establishment media, which once thrived on gathering information, exists solely for anxiety promotion. Confirmation of our greatest fears, from economic collapse to nuclear annihilation, is projected unfiltered on every platform, tailored to match what scares us most. As we like and we share, our fears grow exponentially, leaving us stuck in a frozen state of paranoia. Fear is everywhere. We are afraid Trump will start a war with North Korea, relying on Kim Jong-Un to be a rational actor. We're also afraid Kim will unleash his nuclear arsenal on America and rely on Trump's rational diplomacy to keep international security in check. We're afraid Trump is a Russian puppet and hope the Mueller probe will save us from the death of our democracy. We fear the political goals of Democrats, who hope to overturn a legitimate election using a fake Russia investigation. We're worried the fascist government will suppress free speech and we're worried the government isn't doing enough to suppress free speech to stop hate. There are too many guns for children to be safe, and not enough guns for teachers to protect us. We want to elect more women, people of color, LGBTQ individuals, and Muslims to preserve their rights. We fear women, people of color, LGBTQ individuals, and Muslims as we want to preserve our rights. We are afraid of migrants leaping into our borders and we are terrified of the government cracking down on innocent refugees on the border. As we hyperventilate over an infinite amount of threats, we lash out and grasp whatever form of defense lies closest. This is nothing
\end{abstract}




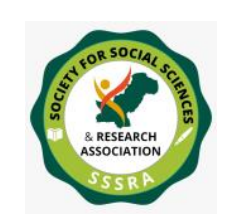

Always at War: An Analysis of ....

new. Those in power have always profited off of fear, but our desire to remain continually plugged in has meant the consequences of such rhetoric are dramatically amplified. The infestation of corporate interests into the political process has created a marriage between our love of capitalism and our culture of fear. This paper examines the real-world impacts of this marriage and the dramatically violent impacts of the corporate exploitation of fear. Ultimately, our constant need to feel secure from a barrage of seemingly never-ending threats has allowed corporations to amass enormous amounts of power, murdering democracy for the sake of profit.

Whether carpet-bombing the arid deserts of Iraq, selling arms to rebel groups in the lush Amazon forest, or provoking civilian ships in the South China Sea, the American military has its grip on every corner of the world. Sailing the oceans of the world, this massive fighting force eats 717 billion dollars every single year, and has a budget that is only expected to increase. Yet while the American war in Afghanistan is entering its eighteenth year, the region seems no more peaceful today than back in 2001. The Taliban control $40 \%$ of land area in the country and the central government fails at creating any meaningful progress towards stability. (Scotti) Iraq has been plunged into chaos, while Syria finds itself in the middle of 2 proxy wars between 4 competing rivals. From regime toppling to drone strikes to CIA black sites, every single aspect of the War on Terror has been an utter failure. The longest and most expensive war in American history has failed on every front and it shows no promise of ever ending. The reason that America continues to throw trillions of dollars at a failing campaign of mass violence is a defense industry intent on maintaining profits at the expense of hundreds of thousands of human lives. An immense military-industrial complex has emerged as a hidden force in US politics and has ensured that America will be locked in a state of endless warfare.

While perpetual war constitutes perpetual losses for families, it also represents perpetual profits for a larger complex of business and government interests. The new military industrial complex is entirely fuelled by a conveniently ambiguous and unseen enemy: the terrorist. In his essay entitled "Manufacturing Threat" Nicolas Pugh explains the 


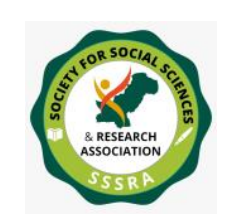

Always at War: An Analysis of

horror of an industry that manipulates public opinion and holds tens of thousands of workers hostage to keep the guns firing. Pugh writes that "defense contractors were active participants in lobbying networks and think tanks [that] provided aggressive policy options to Congress, [...] constructing 'terrorism' as a threat that could only be countered through the use of force and justified military response." (Pugh 4). The more frightened the American public was of the miniscule probability of a terror attack at home, or the possession of weapons of mass destruction abroad, the more money was funneled into the defense industry propping up mass violence. Despite the probability of you dying from a terror attack being "one in 50 million," the threat of terror is exaggerated to ensure constant support (6) Tobias Stockwell continues in his article for the Medium: "there is a profound asymmetry in the coverage of terrorist attacks vs. other types of homicides." The New York Times for examples published as many articles on terror attacks as homicides at home, even though "animals kill more people yearly than terrorists do." (Stockwell).

But even if public support for war wanes, it is eclipsed by the massive political power of the industry. Kelly Krebaum writes for the College of DuPage that "the MIC in the U.S. has ultimately made war more politically appealing." She furthers that "As long as weapons are needed for use in wars overseas, the profits will keep rolling in" and are used to finance "politicians that support the MIC." The ten largest defense contractors in the nation spent almost 100 million dollars lobbying the federal government for continued war. (Krebaum) It is not secret that war is incredibly profitable. Sam Ellis writes for Vox News that the one thing all politicians can get behind is jobs, writing that there are an estimated 800,000 jobs in the US tied to defense. He explains "major defense companies spread their operations across as many states as possible [to] maximize the number of legislators inclined to support the project." (Ellis) Moreover, in 2018 defense spending accounted for nearly half of all America's GDP growth. All of this amounts to a war dependent economy that will never stop its campaigns of violence abroad.

While political corruption ensures failing militaristic policy abroad, the same dynamic takes place at home. Given the profits made by arms 


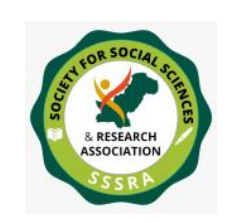

Always at War: An Analysis of ....

manufacturers, the defense industry, gun dealers and the lobbyists who represent them, it comes as no surprise that mass shootings have become routine, innocent children are gunned down in schools, and Congress refuses to reign in a gun lobby that produces a growing culture of fear and violence. Mass fear of violence in the streets has left Americans unable to draft any sort of legislation to address the growing epidemic of gun violence. In her article, "Universal Background Checks Threaten Gun Industry Profits" Amanda Marcotte examines the most basic pieces of common sense gun legislation, universal background checks, are unable to be passed because of fear. Convicted felons and domestic abusers are currently able to gain access to high powered weaponry because of various unaddressed loopholes. Guns bought from private dealers, online, or at gun shows do not have to have a background check. Despite the fact that $90 \%$ of Americans support closing these loopholes, the gun lobby holds the American public hostage using fear and violence all for the sake of profit. Marcotte writes that making sure that criminals can get their hands on guns increases gun industry profits in two ways. First "if criminals are buying their products, gun manufacturers make more money directly." Moreover, even if criminals buy guns on the secondhand market, this increases demand on manufacturers since someone has to buy them 'firsthand' to sell them to the 'secondhand' market. Beyond that "the gun industry benefits from having a lot of well-armed criminals [walking] around, because their presence justifies the purchase of more guns for the non-criminal consumer." (Marcotte) Gun marketing is fear based. Manufacturers, and obviously politicians taking lobby money from them, want people to believe that the streets are clogged up with criminals wielding guns because that's how they convince people to buy more expensive, more powerful guns. If guns stopped falling in the hands of criminals and the nightly news didn't have a relentless flow of gun murders to report on, people might start to believe they're safe and buy fewer guns.

A frightened public armed with deadly weapons has fatal consequences for any semblance of order or criminal justice. An increasingly militarized public necessitates the need for an increasingly 


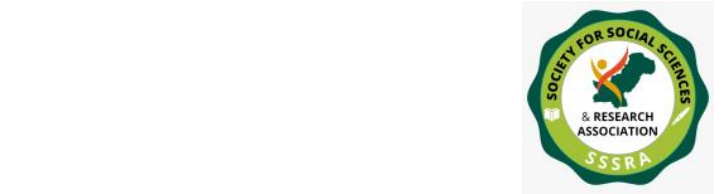

Always at War: An Analysis of $\ldots \ldots \ldots \ldots$

militarized police. In his article, "Ferguson: With So Many Guns In America, Police Are Trained To Live In Fear." Adam Winkler calculates that there are "an estimated 320 million guns in the United States." Winkler explains that "police are equipping themselves with a variety of high-powered firearms because they feel outgunned by the criminals they have to defend themselves against." (Winkler) Because there are so many guns out there, police officers are trained to live in fear of the very people they are supposed to protect and serve. If the public is in fear, so are the police. Continuously afraid that at any moment you might be shot in the back, any individual would cock their rifle and respond with aggression. This mentality breeds only violent responses and pre-emptive judgements based off of race. If cops are forced to mistrust the public for selfprotection, Winkler explains that "it is little surprise that officers often fall back on racial or other stereotypes when faced with the difficult task of quickly determining who is a threat." (Winkler) It is no surprise that America has an increasingly violent police force, that relies on false racial biases brutally murdering unarmed African American men on the streets. It is however, immensely depressing.

In the same way that government policy grows increasingly violent, political rhetoric and journalism is now infused with hatred, fear, and animosity. The most terrifying impact of an obsession with fear-based rhetoric is the mass amount of political apathy it creates while also distorting reality along party lines. In his article "This Is How Your Fear and Outrage Are Being Sold For Profit," Tobias Stockwell argues that news agencies now profit off of perverting and exaggerating news to maximize clicks, and minimize journalistic integrity. Stockwell writes "every time you open your phone, your brain is walking onto a battle ground. The aggressors are the architects of your digital world, and their weapons are the apps, news feeds, and notifications in your field of view." (Stockwell) These belligerents attempt to capture your most scarce resource-our attention-and take it hostage for money. The issue is that modern day news needs to compete with literally everything in our digital library, and it does that by maximizing engagement. The modern social media 'news feed' "shows you stories, tracks your responses, and filters 


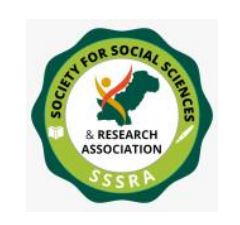

Always at War: An Analysis of ....

out the ones you are least likely to respond to." Ultimately it is mapping your brain, seeking "patterns of engagement." (Stockwell) Using this map, Facebook and other social media sites can create a private personal pipeline of media just for you. This is the reason many of the news stories of today lead with over-the-top, dramatic, and attention-grabbing statements. They are attempting to engage with you and rise above the competition. Because ultimately more clicks mean more exposure to ads and thus more ad revenue.

Our desire to remain continually plugged has severe consequences. Everyday the internet gives us videos of unarmed African American men being shot multiple times. Everyday the internet allows middle school children to answer a fake "Call Of Duty" and unleash mass-murder in cyberspace. Everyday the news breaks stories of children dying in the hallways of their school. Everyday we become desensitized to violence. The average American cares not for the thousands of police officers who face no retaliation from simple murder, nor the white terrorism in schools and churches alike. We literally scroll through the mass murder of innocent civilians in our own nation every single day. When individuals talk about "mass shootings" we must always preface, asking "which one are you referring to?" Technology has removed the harsh brutality of reality. Human beings no longer understand what it means to be gunned down in your own high school. We do not understand what racism is and how bigotry yields dead bodies. Our hearts are stone cold. Technology has shortened our attention spans reducing gun violence to statistics and not real stories of grief and struggle. When change does come it necessitates an overwhelming amount of blood to be spilt. Because we are so numb to violence, we push ourselves to the extremes of extremes before we act. We literally need to stuff young children into cages and separate them from their families before we care about migrants. News is less real to us, and it takes larger, more drastic consequences to cause us to actually act. And when we finally do, any form of real change is unlikely. Carlos Maza writes for Vox News that reality is fractured along party lines. To put it simply, the news a liberal Democrat is exposed to will always be different than what a conservative Republican witnesses. Thus, when voters can not 


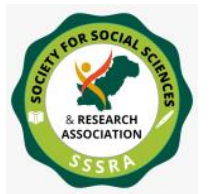

Always at War: An Analysis of

even agree on the status of reality, on what is actually happening, then any form of cohesive change is unlikely. When Democrats and Republicans exaggerate fears like the Migrant Crisis or the Ebola Epidemic in order to scare Americans to vote a certain way, reality is perverted for political causes. The people are left confused as to what is actually happening, destroying the concept of any informed voters. (Maza) Change is not possible when there is no agreed consensus on reality. Technology has left us apathetic to the future, depressed over the thousands of threats posed to us, unable to cooperate on anything.
\end{abstract}

\title{
Conclusion
}

American society is now controlled by fear. Corporate fear has caused widespread anarchy and chaos in the streets termanilizing to an aggressive government that has no will to act in accordance with basic morality. Overseas this same government scares the public into seeing innocent villagers as terrorists that want to decapitate us all. The culture of fear captivates but creates addiction to such consumption of violence and anarchy. We grow addicted and seek more and more fear to consume. Finding nothing and seeing no solution to even illusive problems we grow depressed over the political future of the nation. Political movements and campaigns will always fail because the population doesn't believe in any tangible result. The public is desensitized to violence, does not care, and thus has no capacity for change. We have no ability to find meaningful solutions to our problems because the public is fed with false information provided by massive corporate interests. It has meant our society is never at peace, and always at war.

\section{References}

Ellis, Sam. "This Jet Fighter Is A Disaster, But Congress Keeps Buying It.” Vox Media, Vox News, 26 Jan. 2017.

Krebaum, Kelly. "Capital from Carnage: An Analysis of the Military Industrial Complex.” ESSAI, College of DuPage, 2015. 
Marcotte, Amanda. "Universal Background Checks Threaten Gun Industry Profits, So They Have to Go." Raw Story. Raw Story, 20 Mar. 2017.

Maza, Carlos. "Why Every Election Gets Its Own Crisis." Vox Media, Vox News, 5 Nov. 2018.

Pugh, Nicholas. "Manufacturing Threat: How Defence Contractors Influence the Formulation of US Foreign Policy Objectives." Academia Education, 2015.

Rose-Stockwell, Tobias. "This Is How Your Fear and Outrage Are Being Sold for Profit.” Media, The Medium, 14 July 2017.

Scotti, Ciro. "\$780 Billion US Dollars Later, the Taliban Is Gaining Ground in Afghanistan." Policy + Politics, The Fiscal Times, 1 Nov. 2016.

Winkler, Adam. "Ferguson: With So Many Guns in America, Police Are Trained To Live in Fear." The Huffington Post. Berggruen Institute, 19 Aug. 2014. 